\title{
Phenotypic, Metabolic, and Genetic Diversity of the Indonesian Isolates of Rhizopus oligosporus
}

\author{
CAHYA PRIHATNA ${ }^{1}$ AND ANTONIUS SUWANTO²* \\ ${ }^{1}$ Research and Development Center, Charoen Pokphand Indonesia, P.O. Box 14430, Jakarta, Indonesia \\ ${ }^{2}$ Department of Biology, Institut Pertanian Bogor, Darmaga Campus, Bogor 16680, Indonesia
}

\begin{abstract}
Fifteen Rhizopus oligosporus isolates were isolated from a number of tempeh samples obtained from Mataram, Jember, and Bogor, Indonesia; and subjected for characterization based on phenotypic, metabolic, and genetic fingerprinting through internal transcribed spacer (ITS) regions and amplified fragment length polymorphism (AFLP). Based on the growth on solid medium, they can be divided into three groups. Firstly, isolates that produced thick mycelia, dumpy sporangiophore, and scarce spores in agar culture, the second group is isolates that produced thin mycelia, stretched sporangiophore, with abundant spores in agar culture. The third group that only comprises one isolate, FB-06, is morphologically intermediate of the first and the second groups. These characters correlated with their range of temperature tolerance. The first group is less tolerant to high temperature $\left(45^{\circ} \mathrm{C}\right)$ compared with the second group, and the third group is the most tolerant to temperature up to $45{ }^{\circ} \mathrm{C}$. Metabolic fingerprinting showed a very high polymorphism. In general, the result may explain a correlation in which isolates obtained from the same locations shared similar patterns. There is no correlation found between metabolic fingerprints and their phenotypic fingerprints. Rhizopus oligosporus readily dominated the niche and utilized nearly all carbon sources given demonstrate the versatile nature of this fungus. ITS regions identification revealed single nucleotide polymorphisms in four representative isolates examined, whereas AFLP fingerprinting determined each of representative isolates as individually unique. Furthermore, this AFLP profile seemed to agree with their phenotypic characters.
\end{abstract}

Key words: tempeh, Rhizopus oligosporus, genetic diversity

Tempeh is an Indonesian traditional daily food made of solid-state fermentation of soybean employing foodborne fungus Rhizopus oligosporus. This fungus has undergone a very long employment in that indigenous or traditional "biotechnology" practices in Indonesia. Therefore, it would be of importance to elucidate its biodiversity. However, little has this fungus been studied for its microbiological nature in Indonesia. Tempeh is usually made in farms, in such plain conditions that even the farmers do not have any knowledge regarding the microbiological aspects.

Strain characterization is a preliminary and essential effort in industrial microbiology that can lead to strain improvement and development since the hallmark of such purposes is economic (Crueger and Crueger 1984). Besides of tempeh, $R$. oligoporus has also been used for fermentation of some agricultural by-product to produce nutritionally-improved feed. One may customize strains in such rational manner that fits industrial efficiency since wild strains do not perform well in facilitating the economical aspects of industrial microbiology.

The objectives of this research were to elucidate some biological properties and the biodiversity in terms of morphology, physiology, and genetic polymorphisms of several Rhizopus oligosporus isolates from Indonesia.

\section{MATERIALS AND METHODS}

Culture and Microorganisms. Fourteen Rhizopus oligosporus isolates were isolated from several tempeh samples that were collected from several locations in Bogor,

${ }^{*}$ Corresponding author, Phone/Fax: +62-251-315107, E-mail: asuwanto@indo.net.id
Jember, and Mataram, and one isolate was isolated from commercial inoculum from Lembaga Ilmu Pengetahuan Indonesia (LIPI), Bandung (Table 1). All isolates were grown in potato dextrose agar at $32{ }^{\circ} \mathrm{C}$ for a week and maintained in malt extract agar. One-week-old cultures on malt extract agar were used for morphology, culture, and metabolic fingerprinting examinations.

DNA Isolation. For total DNA isolation, spores suspensions were inoculated into potato sucrose broth and incubated for 3 days at $32{ }^{\circ} \mathrm{C}$ in an orbital shaker $(175 \mathrm{rpm})$. Mycelia were collected by passing them through sieves and air-dried. Approximately $0.2 \mathrm{~g}$ of dried mycelia was ground in mortar using liquid nitrogen. One $\mathrm{ml}$ extraction buffer (50 mM Tris-HCl pH 8.0, 125 mM EDTA pH 8.0, 50 mM NaCl, $0.1 \%$ (v/v) mercaptoethanol, and $2 \%$ (w/v) sodium N-lauryl sarcosinate) was poured into mycelia mats (ground mycelia)

Table 1 List of isolates with their origins based on morphology and culture type

\begin{tabular}{cl}
\hline $\begin{array}{c}\text { Isolate } \\
\text { name }\end{array}$ & \multicolumn{1}{c}{ Origin } \\
\hline FB-1 & Mataram, Nusa Tenggara Barat \\
FB-2 & Monjok, Mataram, Nusa Tenggara Barat \\
FB-3 & Abian Tubun, Mataram, Nusa Tenggara Barat \\
FB-4 & Lembaga Ilmu Pengetahuan Indonesia, Bandung, West Java \\
FB-5 & Taman Baru, Mataram, Nusa Tenggara Barat \\
FB-6 & Jember, East Java \\
FB-7 & Jember, East Java \\
FB-8 & Kekalik, Mataram, Nusa Tenggara Barat \\
FB-18 & Warung Jambu, Bogor, West Java \\
FB-19 & Warung jambu, Bogor, West Java \\
FB-20 & Darmaga, Bogor, West Java \\
FB-21 & Empang, Bogor, West Java \\
FB-22 & Guga Sari, Bogor, West Java \\
FB-23 & Malabar, Bogor, West Java \\
FB-24 & Ciluer, Bogor, West Java \\
\hline
\end{tabular}


and gently ground for the second time until a slurry mat formed. The suspensions were transferred into 1.5 -ml tubes and leaved at bench for 30 minutes. DNA was separated by consecutive extraction using 0.5 -volume Tris-saturated phenol and followed by 0.5 -volume chloroform. The aqueous phase was transferred into a new tube and extracted for the second time using 0.5-volume chloroform. DNA was precipitated with cold isopropanol and sodium acetate followed by cold ethanol wash and stored in Tris-EDTA buffer $\mathrm{pH} 8.0$ at $4^{\circ} \mathrm{C}$.

Morphology and Culture Fingerprinting. All isolates were grown in malt extract agar for a week at $32{ }^{\circ} \mathrm{C}$ in the dark. Morphology observation was performed using light microscopy. The key characteristics examined were sporangiophore, sporangium, sporangiospore, and colony appearance on plates. As a guideline for morphology examination, an atlas for Rhizopus identification was used (Liou et al. 1990). Culture growth characteristics in different temperatures were also observed by growing the isolates in an agar-solidified media of certain feed formulation at 32, 45, and $50^{\circ} \mathrm{C}$.

Metabolic Fingerprinting. Metabolic fingerprinting is based on utilization of an array of certain specific carbon sources resulting in formation of unique pattern of reactions. Reaction and analysis were done using Biolog, Microlog ${ }^{\mathrm{TM}}$ System, Release 4.2 (Hayward, CA, USA). Spores from a week malt-extract-grown cultures were collected and spore density was adjusted to $75 \% \mathrm{~T}$. Spore suspensions were inoculated into 96-wells Biolog Microplate ${ }^{\mathrm{TM}}$ and incubated for 7 days at $32{ }^{\circ} \mathrm{C}$. Plates were read in Biolog Reader Machine and analysed with Microlog ${ }^{\mathrm{TM}}$ software.

Internal Transcribed Spacer Regions Identification. The resulting DNA was used as a template to amplify the ribosomal DNA ITS regions. The ITS primers used were ITS4 (5'-TCCTCCgCTTATTgATATgC-3') and ITS5 (5'ggAAgTAAAAgTCgTAACAAgg-3') (Abe et al. 2003) (Figure 1). DNA was amplified using $1 \times$ PCR buffer, $0.1 \mathrm{ml}$ Taq Polymerase (New England Biolabs, USA), and $100 \mathrm{pmol}$ of each ITS4 and ITS5 primers. The PCR reaction was carried out for 35 cycles of denaturation at $95{ }^{\circ} \mathrm{C}$ for 1 minute, annealing at $50^{\circ} \mathrm{C}$ for 1 minute, and extension at $72^{\circ} \mathrm{C}$ for one minute using an Applied Biosystem 2400 machine. The PCRamplified fragments were purified with MoBio PCR DNA Purification Kit and sequenced in an ABI Prism 3100 Avant Genetic Analyzer.

Amplified Fragment Length Polymorphism. Approximately $300 \mathrm{ng}$ of DNA was subjected for endonuclease II digestion using EcoRI and MseI. The resulting fragments were ligated after the addition of adapters in the EcoRI and MseI restriction sites. Pre-amplification was performed with one-base-extended primers for each adapted sites of EcoRI and MseI (EcoRI+1 primer: 5'-GAC TGC GTA CCAATT CA-3' and MseI+1 primer: 5'-GAT GAG TCC TGA
GTAAC-3'). A touch-down PCR was performed to selectively amplify the resulting pre-PCR products. The primers used were a TGA-base extended of MseI+1 primer and one-baseextended of EcoRI primer (see pre-amplification EcoRI primer sequence). PCR was carried out for 20 cycles of 15 seconds denaturation at $94{ }^{\circ} \mathrm{C}$, annealing at $66^{\circ} \mathrm{C}$ for 15 seconds, with the temperature for each subsequent cycle was lowered by $0.5^{\circ} \mathrm{C}$, and extension at $72{ }^{\circ} \mathrm{C}$ for one minute. Cycling was continued for 30 cycles at an annealing temperature of $56^{\circ} \mathrm{C}$. After completion of the cycles, an additional incubation for 10 minutes at $72^{\circ} \mathrm{C}$ was performed before the reaction mixture was cooled down. A 100-fold dilution of the resulting PCR products were sequenced in an ABI Prism 3100 Avant Genetic Analyzer, and analysed with Genotyper 3.7 and GeneScan 3.7 softwares.

\section{RESULTS}

Morphologically, the isolates can be clearly divided into three groups in accordance to their growth ability in different temperatures. Isolates possessing thin mycelia, dark sporangium, elongated sporangiophore, and abounding spores, were able to grow at $45^{\circ} \mathrm{C}$. In contrast, isolates with thick mycelia, brighter or light sporangium, dumpy sporangiophore, and scarce spores, grew poorly at $45^{\circ} \mathrm{C}$. The third group, which possesses intermediate morphology and culture features between the first and the second groups, belongs to only one isolate, FB-06. Interestingly, the isolate was the most tolerant to temperature of $45^{\circ} \mathrm{C}$. None of the isolates was able to grow at $50{ }^{\circ} \mathrm{C}$. Figure 2 represents sporangium colour of FB-01 and FB-06 isolates.

Individual metabolic fingerprinting showed a very high polymorphism (Table 2). Even though, a specific pattern seemed to correlate with the origin of the isolates. Isolates from Bogor, Jember, and Mataram showed a distinct pattern, but isolates from the same locations shared a similar pattern. However, among all isolates, only FB-01, FB-02, FB-03, FB04, and FB-05 were identified as Rhizopus oligosporus Saito, and the remaining isolates did not indicate the characteristics of any Rhizopus species. This result revealed a high variance in the physiological properties of $R$. oligosporus.

Community fingerprinting analyses indicated that almost all carbon sources were completely utilized in a fermented materials whether the raw materials were sterilized or not (Table 3). However, some carbon sources were not utilized in sterilized materials, while they were utilized in unsterilized materials. Although the pattern was considerably different in both raw materials, major changes appeared during fermentation resulting in quite similar pattern.

The ITS regions identification found single nucleotide polymorphisms in the ITS regions of ribosomal DNA. Figure 3 shows the result of multiple alignment of PCR products of ITS regions of four representative isolates. In the isolate

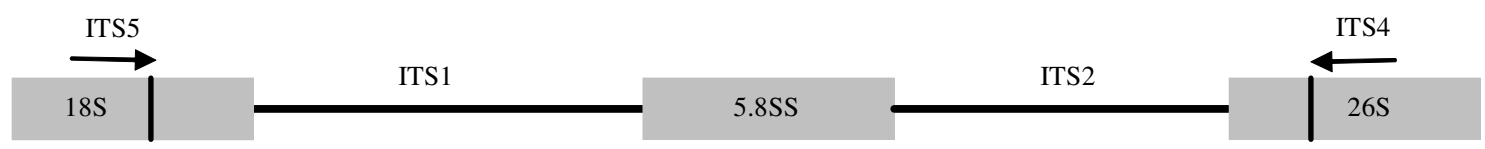

Figure 1 Representation of the ribosomal DNA (rDNA) and internal transcribed spacers (ITS) regions. Sites of ITS4 and ITS5 primers are indicated with arrows. 

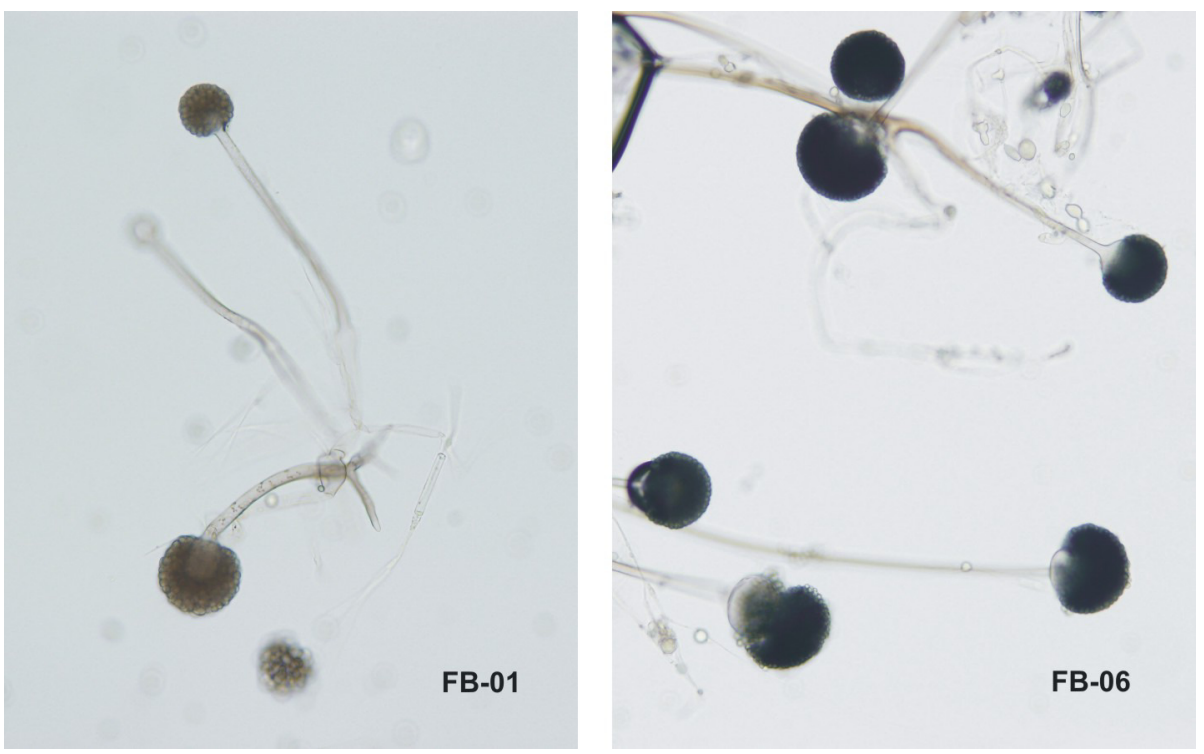

Figure 2 Sporangium colour of Rhizopus oligosporus isolates FB-01 and FB-06. Sporangium of FB-01 is brownish, whereas sporangium of FB-06 is blackish.

Table 2 Metabolic fingerprint of several Indonesian Rhizopus oligosporus isolates

\begin{tabular}{|c|c|c|c|c|c|c|c|c|c|c|c|c|c|c|c|}
\hline \multirow{2}{*}{ Carbon source } & \multicolumn{15}{|c|}{ Rhizopus isolate } \\
\hline & B-01 & FB-04 & FB-02 & FB-03 & FB- 07 & FB-05 & FB-08 & FB-06 & FB-18 & FB-19 & FB-20 & FB-21 & FB-22 & FB-23 & FB-24 \\
\hline \multicolumn{16}{|l|}{ water } \\
\hline $\begin{array}{l}\text { cyclodextrin } \\
\text { D-glucose-1-pho }\end{array}$ & - & - & - & - & - & - & - & - & 二 & - & - & - & - & - & - \\
\hline -mannitol & - & - & - & - & - & - & 二 & 二 & 二 & 二 & 二 & 二 & - & 二 & 二 \\
\hline ribose & 一 & - & - & - & - & - & - & - & - & - & - & - & - & 一 & 一 \\
\hline amy & - & - & - & - & - & - & - & - & - & - & - & - & - & - & 一 \\
\hline D-saccharic acid & & & & $=$ & $=$ & & & & & $=$ & & $=$ & 二 & & \\
\hline $\begin{array}{l}\text { Glycyl-L-glutamic acid } \\
\text { tween } 80\end{array}$ & - & & & - & 二 & 二 & - & 二 & - & - & - & - & - & - & - \\
\hline cyclodextrin & & & & & 一 & & & - & - & & - & & - & - & \\
\hline ide & & & & & & & & & 一 & - & - & - & 一 & - & 一 \\
\hline -mann & - & - & - & - & - & - & - & - & - & - & - & - & - & - & - \\
\hline licin & - & - & - & - & - & 一 & 一 & - & 一 & - & - & - & 一 & 一 & 一 \\
\hline \multicolumn{16}{|l|}{ bromosuccinic acid } \\
\hline sebacic acid & - & - & - & - & - & - & - & - & - & - & - & - & - & - & 一 \\
\hline -ornithine & - & 一 & 一 & 一 & 一 & - & - & - & - & - & - & - & 一 & 一 & 一 \\
\hline \multicolumn{16}{|l|}{$\mathrm{N}$-acetyl-D-galactosamine } \\
\hline extrin & - & - & - & - & - & - & - & - & - & - & - & - & & - & - \\
\hline D-glus & & & & & - & & - & - & - & & - & - & - & - & - \\
\hline -melezitose & & & & & - & & & & - & - & - & - & - & - & \\
\hline \multicolumn{16}{|l|}{ sedoheptulosan } \\
\hline \multirow{2}{*}{\multicolumn{16}{|c|}{ succinamic acid }} \\
\hline & & & & & & & & & & & & & & & \\
\hline L-pheny & - & 一 & - & 一 & 一 & 一 & - & - & - & - & - & - & - & 一 & 二 \\
\hline lucosamine & - & - & - & - & - & - & - & - & - & - & - & - & - & - & - \\
\hline & & & & - & - & & - & - & - & - & - & - & - & - & - \\
\hline /ce & - & 一 & - & 一 & 一 & - & 一 & - & 一 & 一 & & - & - & - & - \\
\hline & & & & & - & & - & - & - & & - & - & & - & \\
\hline D-sorbitol & - & - & - & - & - & - & - & - & - & - & - & - & - & - & - \\
\hline \multicolumn{16}{|l|}{ b-hydroxybutyric acid } \\
\hline ccinic & - & - & - & - & - & - & - & - & - & - & - & - & - & - & - \\
\hline roline & - & - & - & - & - & - & - & - & - & - & - & - & - & - & - \\
\hline \multicolumn{16}{|l|}{$\mathrm{N}$-acetyl-b-D-mannosamine } \\
\hline fruet & - & - & - & - & - & - & - & - & - & - & - & - & & - & - \\
\hline & - & - & - & 一 & 一 & 一 & 一 & 一 & - & - & - & - & - & - & 一 \\
\hline meth & & & & & - & & - & - & - & - & & & - & & \\
\hline sorbos & & & & & - & & & & & & & - & & - & \\
\hline & & & & & & & & & - & 一 & & & - & & \\
\hline mono-methylester & - & - & - & - & - & - & - & - & - & - & - & - & - & - & - \\
\hline & & & & & - & & & & & - & & - & & & \\
\hline Jonito & - & - & - & - & - & 一 & - & - & - & - & - & - & - & - & - \\
\hline 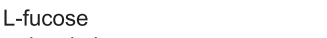 & & & & & & & & & - & & 一 & - & 二 & 一 & - \\
\hline tontogid & & & & & 一 & & - & - & & & - & 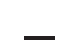 & 二 & 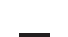 & - \\
\hline D-galactoside & & & & & & & & & $=$ & 二 & $=$ & $=$ & $=$ & 二 & - \\
\hline stachyc & & & & & 二 & & - & - & & 二 & & 二 & & & \\
\hline $\begin{array}{l}\text { p-hydroxyphenyl-acetic acid } \\
\mathrm{N} \text {-acetyl-L-glutamic acid }\end{array}$ & & & & & - & & & & & - & & - & - & & \\
\hline L-serine & - & - & - & - & - & - & - & - & - & - & - & - & - & - & - \\
\hline & & & & & $-5+2$ & $-5+2>$ & & - & & & & & - & & \\
\hline D-galactose & - & - & - & - & - & - & - & - & - & 二 & 二 & - & $=$ & - & $=$ \\
\hline
\end{tabular}


Table 2 Continued

\begin{tabular}{|c|c|c|c|c|c|c|c|c|c|c|c|c|c|c|c|}
\hline Carbon source & FB-01 & FB-04 & FB-02 & FB-03 & FB-07 & FB-05 & FB-08 & FB-06 & FB-18 & FB-19 & FB-20 & FB-21 & FB-22 & FB-2 & FB-24 \\
\hline 2-keto-D-gluconic acid & - & - & $=$ & - & $=$ & & - & - & $=$ & $=$ & $=$ & - & $=$ & - & - \\
\hline a-methyl-D-glucoside & & & & & $=$ & - & & & 二 & & $=$ & $=$ & $=$ & $=$ & \\
\hline a-ketoglutaric acid & - & - & - & - & - & - & - & - & - & - & 二 & 二 & 二 & ב & 二 \\
\hline L-alaninamide & - & - & - & - & & - & & - & - & - & - & - & - & - & - \\
\hline threonine & & & & & - & & & & - & - & - & - & - & & - \\
\hline -arabinose & 一 & - & - & - & - & - & - & - & - & - & - & - & - & - & - \\
\hline D-galacturonic acid & - & - & - & - & - & 一 & - & - & - & & - & & & 一 & \\
\hline tose & & & & & & & & & & & & & - & - & \\
\hline b-methyl-D-glucoside & - & & - & - & - & & - & - & - & - & - & - & - & - & - \\
\hline D-tagatose & & & & & & & 一 & - & - & - & - & 一 & 一 & 一 & - \\
\hline D-lactic acid methyl ester & & & & & & - & & & - & - & - & - & - & - & - \\
\hline L-alanine & - & - & - & - & & - & - & - & - & - & - & - & - & - & - \\
\hline anol & & & & & - & & & & & - & & - & & & \\
\hline L-arabinose & 一 & 一 & - & - & 一 & - & - & - & - & - & - & - & - & 一 & - \\
\hline gentio & 一 & 一 & - & 一 & 一 & 一 & - & 一 & - & - & - & - & & - & - \\
\hline lactulose & & & & & - & & & & & & & & & - & \\
\hline palatinose & & & & & 一 & & & - & - & - & - & - & - & 一 & - \\
\hline trehalose & 一 & 一 & - & 一 & 一 & 一 & 一 & 一 & - & - & 一 & 一 & & - & 一 \\
\hline & & & & & & & & - & - & & & - & - & - & \\
\hline cine & - & - & - & - & - & - & - & - & - & - & - & - & - & - & - \\
\hline & 一 & 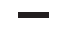 & - & - & - & - & - & - & - & - & - & - & - & - & \\
\hline D-arabitol & - & - & - & - & - & - & - & - & - & & & - & & - & \\
\hline ic acid & 一 & - & - & - & - & - & - & - & - & - & - & - & - & - & - \\
\hline & & & & - & - & & & & - & - & - & $=$ & $=$ & 二 & $=$ \\
\hline ture & & & & & - & & & & - & - & 二 & 二 & 二 & 二 & 二 \\
\hline $\mathrm{cid}$ & & & & & - & & & - & - & - & & - & - & & - \\
\hline ragine & - & - & - & - & - & - & - & - & - & - & - & - & - & - & - \\
\hline & & & & & & 一 & & & & - & & 一 & 一 & & 一 \\
\hline arbuti & & & & & - & - & 一 & - & - & - & - & - & 一 & - & - \\
\hline cosamine & - & - & - & - & - & 一 & - & - & - & & - & - & & - & \\
\hline & - & - & - & - & - & & - & - & - & - & - & - & - & - & - \\
\hline inose & & & & & - & & - & - & - & & & - & 一 & - & \\
\hline xylito & 一 & 一 & - & 一 & 一 & - & 一 & 一 & - & - & & - & & - & - \\
\hline L- & - & - & - & - & - & & & - & - & - & - & - & - & - & - \\
\hline L-aspartic acid & - & 一 & - & 一 & 一 & 一 & 一 & 一 & - & - & - & - & - & - & - \\
\hline & & & & & & & & & & - & & - & 一 & & - \\
\hline ellobios & - & - & - & - & - & & 一 & - & - & - & & - & & - & - \\
\hline a-D-glucose-1-phosphate & - & - & - & - & - & - & - & - & - & - & - & - & & - & - \\
\hline maltotrios & - & - & - & - & - & - & 一 & - & - & - & - & - & 一 & - & - \\
\hline L-rhamnose & & & & & - & & - & - & - & - & - & - & - & - & \\
\hline D-xylose & - & 一 & - & 一 & 一 & 一 & 一 & 一 & - & 一 & - & - & - & - & - \\
\hline L-glutami & - & - & - & - & - & - & E & $=$ & 二 & E & - & 二 & $=$ & - & 二 \\
\hline $\begin{array}{l}\text { L-glutamic acid } \\
\text { adenosine-5'-monophosphate }\end{array}$ & & & & & & & & & & - & & - & - & & - \\
\hline
\end{tabular}

Table 3 Fingerprint of microbial community-level of feed sample before and after fermentation using Rhizopus oligosporus isolate FB-01

\begin{tabular}{|c|c|c|c|c|}
\hline Carbon source & raw nonsterilized & fermented nonsterilized & raw sterilized & fermented sterilized \\
\hline $\begin{array}{l}\text { water } \\
\beta \text {-Methyl-D-Glucoside }\end{array}$ & - & & & \\
\hline \multirow{2}{*}{\multicolumn{5}{|c|}{$\begin{array}{l}\text { D-Galactonic Acid y-Lactone } \\
\text { L-Arginine }\end{array}$}} \\
\hline & & - & & \\
\hline D-Xylose & - & - & - & - \\
\hline D-Galacturonic Acid & - & - & - & - \\
\hline L-Asparagine & - & - & - & - \\
\hline Tween 40 & - & & & - \\
\hline i-Erythritol & - & - & & - \\
\hline 2-Hydroxy Benzoic Acid & & - & & - \\
\hline L-Phenylalanine & - & - & - & - \\
\hline Tween 80 & - & & & \\
\hline \multicolumn{5}{|l|}{ D-Mannitol } \\
\hline 4-Hydroxy Benzoic Acid & & - & & - \\
\hline L-Serine & & - & & - \\
\hline a-Cyclodextrin & & - & - & - \\
\hline N-Acetyl-D-Glucosamine & - & - & - & - \\
\hline y-Hydroxybutyric Acid & - & - & & - \\
\hline L-Threonine & - & - & & - \\
\hline Glycogen & - & - & & - \\
\hline D-Glucosaminic Acid & - & - & & - \\
\hline Itaconic Acid & - & - & & - \\
\hline Glycyl-L-Glutamic Acid & - & - & & - \\
\hline D-Cellobiose & - & & & - \\
\hline Glucose-1-Phosphate & - & - & & - \\
\hline a-Ketobutyric Acid & & - & & \\
\hline Phenylethyl-amine & & - & & - \\
\hline \multicolumn{5}{|l|}{$\alpha$-D-Lactose } \\
\hline D,L-a-Glycerol Phosphate & - & - & & - \\
\hline D-Malic Acid & & & & - \\
\hline Putrescine & & - & & - \\
\hline
\end{tabular}


Figure 3 Multiple alignment of rDNA ITS regions of Rhizopus oligosporus isolates FB-02, FB-03, FB-07, and FB-08.

Table 4 The summarized fingerprint of amplified fragment length polymorphism result of Rhizopus oligosporus isolates FB-01, FB05, FB-06, and FB-08

\begin{tabular}{ccccc}
\hline $\begin{array}{c}\text { Fragment size } \\
\text { (base pairs) }\end{array}$ & FB-01 & FB-06 & FB-08 & FB-05 \\
\hline 380 & - & - & - & - \\
353 & - & & - & \\
323 & - & - & - & - \\
300 & - & - & - & - \\
256 & - & - & - & - \\
248 & - & - & - & - \\
241 & - & & - & - \\
213 & - & - & - & - \\
209 & - & & - & - \\
206 & - & - & - & - \\
196 & - & - & - & - \\
174 & - & - & - & - \\
165 & - & & - & - \\
154 & - & - & - & - \\
126 & - & - & - & - \\
124 & - & - & - & - \\
113 & - & - & - & - \\
110 & - & - & - & - \\
109 & & - & - & - \\
74 & & - & - & - \\
55 & - & - & - & - \\
\hline
\end{tabular}

FB- 07 , the $36^{\text {th }}$ base was replaced by $\mathrm{A}$, and in the isolate FB03 , the $271^{\text {st }}$ base was replaced by $A$ and the base was lost in the others, $307^{\text {th }}$ base by C, $318^{\text {th }}$ base by A and the base was lost in the others, and the $336^{\text {th }}$ base by $\mathrm{A}$ and also the base was lost in the others.

The amplified fragment length polymorphism analysis showed high polymorphism among four representative isolates (Table 4). The result showed that each of representative isolates was individually unique. Isolates FB-
05 and FB-08 share closer relationship compared with the others. Isolate FB-06 exhibits a distinct fingerprint as to a number of fragments was not amplified.

\section{DISCUSSION}

Rhizopus oligosporus and its allies have undergone

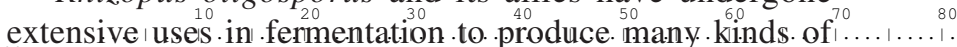
-02 a TTGA TT AGAT ATAGTTAAAGAT ATTAAGATAT TG TGG TAG AGAA TAGATTATATGTTTTTTGGTTGGA AA FB-draditional-foods such as tempeh; kecap; and tauco. Despite

FB-qłts extensive employment for hundreds of years in Indonesia; recognition of its hicrobiologicallodiversity still ${ }^{\circ}$ needs ${ }^{90}$

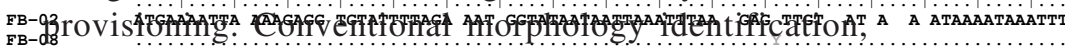
${ }_{\mathrm{FB}-\mathrm{CH}_{3}}$ owever time-consuming and laborious; still provides a

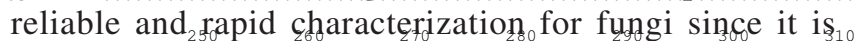

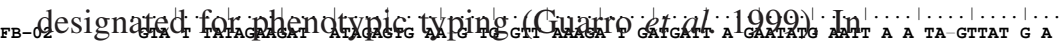

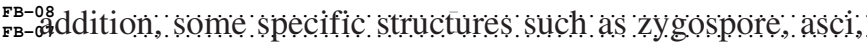

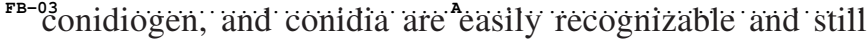
considered as the most important sets of characterilstics to ${ }^{430}$ FB-dge $\underset{\mathrm{FB}-03}{\mathrm{FB}-07}$ In general, from the microsepic and macroscopic observations ${ }_{3}$ in accordance with theiro growthoability $y_{4}$ in high 50 560

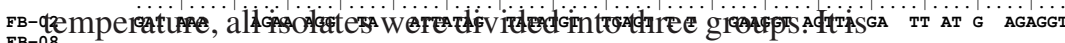
${ }_{F B-03}^{F B-08}$ teresting to note about the correlation of a certain morphological pattern with the high temperature tolerance.

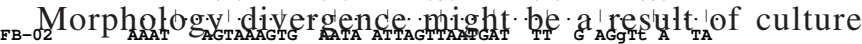
${ }_{\mathrm{FB}-\mathrm{g} g}$ egeneration ('spontaneous mutation) or sexual interaction FB-qzetween strains of opposite sex that can lead to hyphal morphology modification in the progeny (Mehta and CerdáOlmedo 2001). These mutation and sexual interaction are assumed, in turn, also modified the genetic trait of high temperature tolerance. It is also known that some species in the phylum Zygomycota have considerable morphological variation (Benny 1994; Weitzman et al. 1995) and several species are thermophilic (de Hoog and Guarro 1995).

Biochemical and physiological tests have also been used for identification of zygomycetes especially for clinically important strains. Nevertheless, there are some major 
drawbacks restraining the approach, which is rather complicated. The procedure is both time-consuming and labour-intensive and usually requires special media, some of which are not commercially available (Kaufman et al. 1990). Here, we used a relatively simple, reliable, and high throughput identification kit, Biolog, Microlog ${ }^{\mathrm{TM}}$ System, Release 4.2 (Hayward, CA, USA).

In our experiment, physiological characterization did not elucidate its correlation with the morphology fingerprint. However, it explicated an itinerary to the conjecture that the same origin of location of the isolates has the similar metabolic fingerprint. Even though some of the isolates were not recognized as Rhizopus oligosporus according to the Biolog, Microlog ${ }^{\mathrm{TM}}$ System test, and only of those isolates from Mataram were identified as $R$. oligosporus, it demonstrated that there is a remarkable metabolic diversity of $R$. oligosporus.

Recalling that Biolog uses database-based identification, we assumed that isolates from Bogor and Jember have undergone major changes in their physiological properties throughout their evolutionary flow. Evolution on type of nutrition appears to have progressed in the order Mucorales, resulting in great diversity of nutritional requirements (Hesseltine 1955). Recalling the rapid growth nature of $R$. oligosporus, it seems conceivable that this fungus has encountered relatively rapid evolution.

Analysis on community level concluded that similar fingerprint after fermentation of unsterilized and sterilized raw materials revealed that $R$. oligosporus outstandingly outcompete the niche and readily predominate the utilization of available nutrition. However, it is important to note that even in sterilized raw materials it still produced positive reactions, indicating the presence of highly heat-resistant microorganisms. We assumed that these microorganisms might be endospore-forming bacteria.

This approach can also provide a vast amount of information that might be useful for other applications. Once the community fingerprint in solid-state fermentation employing $R$. oligosporus has been established in such optimal conditions, one may use the information for microbiological quality control of the fermentation process by monitoring changes occurred in the fingerprints.

Phenotypic as well as metabolic characters are not always collinear with their genetic designation, the so-called epigenetic phenomenon. The distinct pattern between isolate FB-03 and isolates FB-02 and FB-07, which are obviously similar in their morphology and metabolic fingerprint, may be explained by the fact that rDNA ITS regions do not encode functional proteins and are spliced out after transcription. Abe et al. (2003) also found that certain strain of Amylomyces rouxii shares completely the same ITS sequence with Rhizopus oryzae. The ITS regions are much more variable, but sequences can be aligned with confidence only between closely related taxa. These regions are generally used for species differentiation but may also demonstrate patterns of microevolution (Gräser et al. 1999).

Regardless of some weaknesses, the AFLPs may provide the most determinative in term of genetic resolution produced (Mueller and LaReesa Wolfenbarger 1999; Brugmans et al. 2003). In our experiment, there is no single isolate that has the same pattern with others. It is interesting to note that the AFLP fingerprints of isolates FB-01, FB-05, FB-06, and FB08 differentiated these isolates accordingly to their phenotypic (morphology and temperature tolerance) differentiation. Isolates FB-05 and FB-08 are morphologically similar, but isolates FB-01 and FB-06, each of them is morphologically different to the others. The AFLP result revealed that isolates FB-05 and FB-08 have similar genetic fingerprints. On the other hand, isolates FB-01 and FB-06, each of them has dissimilar AFLP fingerprints to the others. Unlike the rDNA ITS regions, AFLP result may also evidence the phenotype, because AFLP fingerprints the whole genome. Reliable genetic resolution greatly depends on appropriate primers and PCR methods selections. The use of TGA bases extension in combination with specific touch-down PCR method has proven to generate sufficient genetic resolution.

\section{REFERENCES}

Abe A, Sone T, Sujaya I Nengah, Saito K, Oda Y, Asano K, Tomita F. 2003. rDNA ITS sequence of Rhizopus oryzae: Its application to classification and identification of lactic acid producers. Biosci Biotechnol Biochem 67:1725-1731.

Benny GL. 1994. Classical morphology in zygomycete taxonomy. Can J Bot 73:725-730.

Brugmans B, van der Hulst RGM, Visser RGF, Lindhout P, van Eck HJ. 2003. A new and versatile method for the successful conversion of AFLP markers into simple single locus markers. Nucleic Acid Research 31:1-9.

Crueger W, Crueger A. 1984. Biotechnology: a Textbook of Industrial Microbiology. Sunderland: Sinauer Associates.

de Hoog GS, Guarro J. 1995. Atlas of Clinical Fungi. Baarn: Centraalbureau voor Schimmelcultures.

Gräser Y, El Fari M, Presber W, Sterry W, Tietz HJ. 1998. Identification of common dermatophytes (Trichophyton, Microsporum, Epidermophyton) using polymerase chain reactions. Br J. Dermatol 138:576-582.

Guarro J, Gené J, Stchigel AM. 1999. Developments in fungal taxonomy. Clin Microbiol Rev 12:454-500.

Hesseltine CW. 1955. Genera of Mucorales with notes on their synonymy. Mycologia 47:344-363.

Liou GY, Chen CC, Chien CY, Hsu WH. 1990. Atlas of the Genus Rhizopus and its Allies. Mycological Monograph No. 3. Taiwan: Food Industry Research and Development Institute.

Mehta BJ, Cerdá-Olmedo E. 2001. Intersexual partial diploids of Phycomyces. Genetics 158:635-641.

Mueller UG, LaReesa Wolfenbarger L. 1999. AFLP genotyping and fingerprinting. Tree 14:389-394.

Weitzman IS, Whittier J C, McKitrick, Della-Latta P. 1995. Zygospores: the last word in identification of rare and atypical zygomycetes isolated from clinical specimens. J Clin Microbiol $33: 781-783$ 
